\title{
Antioxidant and anti-dermatophytic properties leaf and stem bark of Xylosma longifolium clos
}

\author{
Wangkheirakpam Radhapiyari Devi, S Brojendro Singh and Chingakham B Singh ${ }^{*}$
}

\begin{abstract}
Background: The present study was carried out to assess the phytochemical and anti-dermatophytic effect of the leaf and bark extracts of Xylosma longifolium Clos. The leaf and stem bark are used by the indigenous people of Manipur, India for treatment of skin diseases.

Methods: The leaves and stem barks of Xylosma longifolium were extracted using petroleum ether, chloroform and methanol respectively. The different extracts of each plant parts were tested for antioxidant activity using DPPH assay. The phenolic content was assayed using Folin-Ciocalteu colorimetric method. Each extracts was further analysed by RP-HPLC to quantify some individual flavonoid components. The anti-dermatophytic activity was evaluated both by agar diffusion method and micro wells dilution method against the Microsporum boullardii MTCC 6059, M. canis (MTCC 2820 and MTCC 32700), M. gypseum MTCC 2819, Trichophyton ajelloi MTCC 4878, T. rubrum (MTCC 296 and MTCC 3272).

Results: The free radical scavenging activity values were ranged from 0.7 to $1.41 \mathrm{mg} / \mathrm{ml}$ and 0.6 to $1.23 \mathrm{mg} / \mathrm{ml}$, respectively for leaf and stem bark extracts. The amount of total phenolic contents of the extracts occurred in both leaf and bark in the range of 12 to $56.6 \mathrm{mg}$ GAE/100 $\mathrm{g}$ and 16 to $58 \mathrm{mg}$ GAE/100 g respectively. RP-HPLC analysis for flavonoids revealed the presence of two major flavonoid compounds, rutin and catechin. Kaempferol was in trace or absent. Methanol leaf extract showed significant low inhibitory effect against tested fungus Trichophyton ajelloi MTCC $4878(0.140625 \mathrm{mg} / \mathrm{ml})$ as the most sensitive. These finding suggest that the methanol leaf extract tested contain compounds with antimicrobial properties.
\end{abstract}

Conclusion: The results of our study may partially justify the folkloric uses on the plant studied and further provide an evidence that the leaf extract of Xylosma longifolium might be indeed a potential sources of antimicrobial agents.

Keywords: Xylosma Longifolium, Phenolic, Flavonoid, Antioxidant, RP-HPLC, Anti-Dermatophytic

\section{Background}

Medicinal plants are known to be sourced of diverse nutrients and non-nutrient molecules. Many of the medicinal plants display antioxidant and antimicrobial properties which can protect the human body against both cellular oxidation reactions and pathogens. Antioxidants are vital substances which possess the ability to protect the body from damage caused by free radical induced oxidative stress [1]. There is an increasing interest in natural antioxidants, e.g., polyphenols, present in medicinal and dietary plants, which might help to prevent oxidative damage [2]. The presence of phenolic compounds (phenolic acids, polyphenols and flavonoids) in plants, herbs and spices,

\footnotetext{
* Correspondence: kishore.ibsd@nic.in

Medicinal and Horticultural Plant Resources Division, Institute of Bioresources and Sustainable Development, Imphal 795001, Manipur, India

1, Manipur,
}

is gaining increasing attention because of their various functions, such as antioxidant activity and health benefits [3]. Thus, it is important to characterize different types of medicinal plants for their antioxidant and antimicrobial potentiality [4-6]. Medicinal plants are known to produce certain bioactive molecules which are responsible for their antimicrobial properties [7-10]. The substances that can inhibit pathogens and have little toxicity to host cells are considered as candidates for developing new antimicrobial drugs.

The incidence of dermatophytic infections has increased considerably during the past several decades [11]. Dermatophytes are responsible for serious human pathogenic disorders in various parts of the world. Although control measures are available, they have limited effectiveness. Conventional antifungal agents such as chlorohexidine and

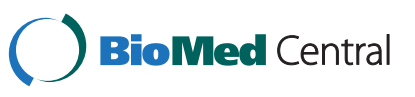


imidazole derivatives have limited uses. Due to their common side effects such as hepatotoxicity, nausea, diarrhoea and impotency [12], the use is restricted in pregnant and the young people.

In order to identify and develop the novel antimicrobial agent, a number of essential oils and extracts have been investigated extensively to achieve higher levels of human safety standards $[13,14]$. The screening of such natural products may offer potential resources since their use is widespread.

Xylosma longifolium Clos. (Flacourtiaceae) is a medium sized tree, distributed in subtropical Himalaya, North-East India and East to West China. In India, X. longifolium is grown for its edible fruits [15], used in Assam, for intoxication, and also exhibits antispasmodic, dysentery, restlessness and insomnia [15,16] and also in Manipur, the fresh leaf and stem bark extracts is also used for curing ringworm, scabies and acne in folk medicine [17].

Medicinal substances from plant species of genus Xylosma exhibit antispasmodic, narcotic, and sedative [18] and against spider bites [19]. Methanol leaf, stem and root of $X$. terrae-reginae show antioxidant activity $\left(\mathrm{IC}_{50}\right)$ from 10, 9.7 and $10.5 \mu \mathrm{g} / \mathrm{ml}$ respectively [20]. The root extract of $X$. terrae-reginae, the fractions of the leaves and barks of the roots of $X$. ciliatifolium and methanol leaf extract $X$. congestum result antibacterial activity [20-23]. Two new glucosides, 3-methoxy4-hydroxyphenylpropane-7, 8-(6'-benzoyl-2', $1^{\prime}$-O- $\beta$ glucopyranosyl)-7, 8, 9-trio, and 2-hydroxyphenyl-4caffeoyl- $\beta$-d-glucoside, together with seven known compounds are isolated from the stem bark of $X$. longifolia and 8-hydroxy-6-methoxy-pentylisocoumarin exhibits against Mycobacterium tuberculosis [24]. The methanolic extract of the leaves of $X$. longifolium isolate $\beta$-sitosterol, $\beta$-amyrin, friedelin, olean-12-en-3 $\alpha$-ol-28-oic acid $3 \alpha$-D-glucopyranoside [25], flavonoid kaempferol-3 - $\beta$-xylopyranoside-4'- $\alpha$-rhamnoside [26]. The aqueous and alcoholic leaf extracts of X.longifolium was investigated against bacterial and fungal strains [26].

There is no information available regarding the utilization of $X$. longifolium as a source of anti-dermatophytes. Therefore, the present objectives of this study are to evaluate its leaf and barks extracts for antidermatophytic properties which is used in folk medicine in Manipur, India as well as to find its chemical profiles such as total phenol, antioxidants and its flavonoids using three organic solvents with different polarity (petroleum ether, chloroform and methanol) for extraction.

\section{Methods}

\section{Plant materials}

The stem barks and leaves $X$. longifolium were collected from Imphal, Manipur, India. The plant material was identified by Botanical Survey of India, Kolkata and the herbarium voucher sample (WR234) was deposited in the Departmental Herbarium.

\section{Plant extract}

$500 \mathrm{~g}$ of shade-dried pulverized plant materials were subjected to extraction in a Soxhlet apparatus successively with petroleum ether, chloroform and methanol, the volume of each solvent was 6 times the volume of plant extract. For each solvent, extraction was conducted until no more coloured matter was extracted. Solvent from each extracted mixture was evaporated to dryness using a rotary evaporator under reduce pressure at $40^{\circ} \mathrm{C}$. All dried extracts were then kept in tightly fitting stopper bottles and stored in $-4^{\circ} \mathrm{C}$.

\section{Determination of total phenolic contents}

The total phenolic content (TPC) in the extracts was determined by the Folin-Ciocalteu colorimetric method given by Singleton \& Rossi [27]. Different concentrations of extracts were mixed with $1.0 \mathrm{ml}$ of 10 fold diluted Folin-Ciocalteu reagent and $1 \mathrm{ml}$ of saturated sodium carbonate solution. After allowing it to stand for $30 \mathrm{~min}$ at $30^{\circ} \mathrm{C}$, the absorbance was measured at $725 \mathrm{~nm}$ with a UVVisible spectrophotometer (Multiskan Spectrum, Thermo Scientific). Standard curve of gallic acid solution (10, 20, 40, 60, 80 and $100 \mathrm{ppm}$ ) was prepared using the similar procedure. Total phenolic was calculated using a standard gallic acid curve and results were expressed as mg gallic acid equivalent (GAE)/100 g of extract.

\section{DPPH radical scavenging assay}

The scavenging activity of extracts on DPPH was determined using the method described by [28]. This method depends on the reduction of purple DPPH to a yellow coloured diphenyl picrylhydrazine. The determination of the disappearance of free radicals was done using UV-visible spectrometer (Multiskan Spectrum, Thermo Scientific). The remaining DPPH which showed maximum absorption at $517 \mathrm{~nm}$ was measured. Each plant extract sample's stock solution $(1.0 \mathrm{mg} / \mathrm{ml})$ was diluted to final concentrations of $(0.6 .0 .5,0.4,0.3,0.2,0.1,0.05$ and 0.01$) \mathrm{mg} / \mathrm{ml}$, in ethanol. One $\mathrm{ml}$ of a $0.3 \mathrm{mM}$ DPPH ethanol solution was added to $2.5 \mathrm{ml}$ of sample solution of different concentrations. These are test solutions. One $\mathrm{ml}$ of ethanol was added to $2.5 \mathrm{ml}$ of sample solution of different concentration. These are blank solutions. One $\mathrm{ml}$ DPPH solution plus $2.5 \mathrm{ml}$ of ethanol was used as a negative control. The blank for this solution is ethanol. As DPPH is sensitive to light, it is exposed to the minimum possible light. These solutions were allowed to react at room temperature for $30 \mathrm{mi}-$ nutes. The absorbance values were measured and converted into the percentage antioxidant activity using 


$$
\text { Scavenging capacity }(\%)=100-\left[\begin{array}{l}
\text { (absorbance of sample-absorbance of blank }) \\
\times 100 / \text { absorbance of control }
\end{array}\right]
$$

the following equation:

The tests were done in triplicate. The $\mathrm{SCa} 50$ values were calculated by linear regression of plots, where the abscissa represents the concentration of the tested plant extracts and the ordinate the average percent of scavenging capacity. The concentration of sample required to scavenge $50 \%$ of DPPH (SCa50) were determined.

High performance liquid chromatography (HPLC) analysis The flavonoid compounds present in the polar solvents can be separated by using Reverse Phase HPLC equipped with a photo-diode array detector (RP-HPLCPDA). This establishes the light absorbance spectrum from visible and UV wavelengths of each detected compound, and show intense absorption in the UV region of the spectrum. Identification of the flavonoid compounds (Rutin, Catechin, Kaempferol) present in the extracts of leaves and barks of $X$. longifolium was performed on a Waters HPLC system equipped with reversed phase X-bridge ${ }^{\text {тм }}$ C18 $(4.6 \mathrm{~mm} \times 250 \mathrm{~mm}$ i.d. $5 \mu \mathrm{m})$ column (Waters). The column temperature was set at $26^{\circ} \mathrm{C}$ [29]. Using a binary pump (Waters, Model No. 1525) on a binary solvent system consisting of (A) acetonitrile and (B) water in the ratio of $(80: 20 \mathrm{v} / \mathrm{v})$ as mobile phase in isocratic mode with a constant flow rate of $1 \mathrm{ml} / \mathrm{min}$. this was monitored at an absorbance of 259, 280 and $360 \mathrm{~nm}$ each of Rutin [30,31], Catechin [30,32] and Kaempferol [33] respectively, using a UVdetector (Photo-Diode Array, Waters Model No. 2996). The sample injection volume was $20 \mu \mathrm{l}$. The compounds were identified by comparing with standards of each identified compound using the retention time, the absorbance spectrum profile and also by running the samples after the addition of pure standards. The concentration of an individual flavonoid compounds (Rutin, Catechin, Kaempferol) in the plant extract was calculated based on peak height measurement and then finally converted to $\mathrm{mg}$ flavonoid/100 g DW.

\section{Preparation of standard solutions}

The standard solutions were prepared by dissolving each of the standards (namely Rutin, Catechin, Kaempferol) separately in methanol (HPLC grade) using serial dilutions. 10ppm was chosen as the optimum concentration which was within the detection range.

\section{Microorganisms}

The human skin infectious fungal pathogens used in the study (Microsporum boullardii 6059, M. canis (2820 and 3270), M. gypseum 2819, Trichophyton ajelloi 4878, T. rubrum (296 and 3272) were collected from Microbial Tissue Collection Culture (MTCC), Chandigarh, India. All the strains are maintained on sabouraud dextrose agar (SDA, Hi-Media) at $4^{\circ} \mathrm{C}$.

\section{Preparation of the spore suspension and test sample}

The fungi were grown on SDA plates at $32 \pm 2^{\circ} \mathrm{C}$ for $7-9$ days, after which the spores were harvested from sporulation colonies and suspended in sterile normal saline water $(0.9 \%)$. The turbidity of the resulting suspension was compared to $0.5 \mathrm{McF}$ arland turbidity standards. The level of turbidity was equivalent to approximately $1.0 \times 10^{8}$ spores $/ \mathrm{ml}[34,35]$.

\section{In vitro anti-dermatophytic susceptibility assay Disc diffusion assay}

The in vitro anti-dermatophytic activity of the extracts was assessed by agar well diffusion method using SDA in $10 \mathrm{~cm}$ petri dishes [36]. Six wells were pierced using sterile $6 \mathrm{~mm}$ diameter cork borer in the agar, equidistant, and away from the border. Different concentrations of the extracts $(9,4.5,2.25,1.125 \mathrm{mg} / \mathrm{ml})$ were prepared by two-fold dilution method. The graded concentrations of the extracts $(20 \mu \mathrm{l})$ were deposited into the wells using micropipettes and left for $10 \mathrm{~min}$ at room temperature for diffusion. Negative and positive control was prepared using DMSO (final concentration of the DMSO in the highest concentration of plant extract tested did not exceed $0.4 \%(\mathrm{v} / \mathrm{v})$ and did not affect the cell proliferation) and Amphotericin-B $(16 \mu \mathrm{g} / \mathrm{ml})$, respectively. The plates were inoculated at $32 \pm 2^{\circ} \mathrm{C}$ for $7-9$ days. The experiment was repeated thrice and the average results were recorded in radial $(\mathrm{mm})$.

\section{Determination of minimum inhibitory concentration}

Minimum inhibitory concentrations were determined using the micro wells dilution method [37]. The minimum inhibitory concentrations (MICs) of the crude extracts were determined by two fold serial dilution against the pathogens. Six microliter samples of tested extracts were dissolved in the DMSO (99.5\%) employed to isolate and extract the crude extracts. These solutions were serially diluted with the DMSO and were added to sabouraud dextrose broth (SDB) at final concentrations of 
$0.0703125,0.140625,0.28125,0.5625,1.125,2.25,4.5$, $9 \mathrm{mg} / \mathrm{ml}$. A $10 \mu \mathrm{l}$ spore's suspension $\left(1.0 \times 10^{8}\right.$ spores $\left./ \mathrm{ml}\right)$ of each test pathogens was inoculated in the test tubes in $\mathrm{SDB}$ medium and incubated at $32 \pm 2^{\circ} \mathrm{C}$ for $2-7$ days. The control tubes containing SDB medium were inoculated only with fungal spore suspension. The minimum concentrations at which no visible growth were observed was defined as the MICs, which were expressed in $\mathrm{mg} / \mathrm{ml}$.

\section{Statistical analysis}

Sampling proceeds on three independent replications $(n=3)$ for each analytical parameters. Results presented in tables were reported as means \pm standard deviation (SD). Data were subjected to one-way analysis of variance ANOVA, and the significant difference between means was determined by Duncan's multiple range test. Differences at $P<0.05$ were considered statistically significant. Coefficients of determination $\left(r^{2}\right)$ were calculated using Microsoft Excel 2010.

\section{Results}

\section{TPC and DPPH scavenging activity}

The total phenolic contents of the extracts from both leaf and bark (petroleum ether, chloroform and methanol) of $X$. longifolium were tested, and occurred in the range of $12 \pm 1.27$ to $56.6 \pm 4.84 \mathrm{mg} \mathrm{GAE} / 100 \mathrm{~g}$ and $16 \pm$ 1.2 to $58 \pm 2.25 \mathrm{mg} \mathrm{GAE} / 100 \mathrm{~g}$ respectively (Table 1$)$. The total phenolic content of various leaf and bark extracts of petroleum ether, chloroform and methanol were noted to be $12 \pm 1.27,34.6 \pm 2.04$ and $56.6 \pm 4.84 \mathrm{mg} \mathrm{GAE} /$ $100 \mathrm{~g}$ and $16 \pm 1.2,37.6 \pm 2.1$ and $58 \pm 2.25 \mathrm{mg} \mathrm{GAE} / 100 \mathrm{~g}$ of dry extract, respectively.

The DPPH free radical scavenging activity of the both leaf and bark extracts (petroleum ether, chloroform and methanol) of $X$. longifolium was studied (Table 1). The $\mathrm{SCa}_{50}$ values of both leaf and bark extracts were recorded in the range of $0.7 \pm 0.2$ to $1.4 \pm 0.04 \mathrm{mg} / \mathrm{ml}$ and $0.6 \pm 0.17$ to $1.23 \pm 0.56 \mathrm{mg} / \mathrm{ml}$, respectively.

Table 1 The total phenolic, its flavonoid and $\mathrm{SCa}_{50}$ of Xylosma longifolium extracts

\begin{tabular}{|c|c|c|c|c|c|c|}
\hline \multirow{2}{*}{\multicolumn{2}{|c|}{$\begin{array}{l}\text { Type of } \\
\text { extract }\end{array}$}} & \multirow{2}{*}{$\begin{array}{c}\text { Total phenolic } \\
\text { content } \\
(\mathrm{mg} / 100 \mathrm{~g})\end{array}$} & \multirow{2}{*}{$\begin{array}{c}\mathrm{SCa}_{50} \\
(\mathrm{mg} / \mathrm{ml})\end{array}$} & \multicolumn{3}{|c|}{ Individual flavonoids (\%) } \\
\hline & & & & Rutin & Catechin & Kaempferol \\
\hline \multirow[t]{3}{*}{ Leaf } & PE & $12 \pm 1.27^{b}$ & $0.7 \pm 0.2^{a}$ & 0.67 & 4.29 & 0 \\
\hline & $\mathrm{CH}$ & $34.6 \pm 2.4^{d}$ & $1.3 \pm 0.12^{a}$ & 0.65 & 1.73 & 0.03 \\
\hline & $\mathrm{ME}$ & $56.6 \pm 4.84^{h}$ & $1.4 \pm 0.04^{a}$ & 0.56 & 1.24 & 0.08 \\
\hline \multirow[t]{3}{*}{ Bark } & $P E$ & $16 \pm 1.2^{b}$ & $0.6 \pm 0.17^{a}$ & 0.51 & 1.88 & 0 \\
\hline & $\mathrm{CH}$ & $37.6 \pm 1.94^{c}$ & $1.0 \pm 0.35^{a}$ & 0.22 & 1.56 & 0.021 \\
\hline & ME & $58 \pm 2.25^{d}$ & $1.23 \pm 0.56^{b}$ & 0.12 & 1.72 & 0.07 \\
\hline
\end{tabular}

$\mathrm{PE}$ - petroleum ether, $\mathrm{CH}$ - chloroform, $\mathrm{ME}$ - methanol.

Means \pm SD of triplicates. For each column, values followed by one or more of the same letters were not significant different at $P<0.05$.

\section{Flavonoid compounds analysis}

The solvent extracts were analysed by HPLC to quantify the selected parts of the plant. The established HPLCUV method was successfully applied for the determination of the three major flavonoid compounds (Rutin, Catechin, Kaempferol) present in different parts of the plant, $X$. longifolium. The contents of these compounds distributed in different parts of the plant, bark and leaf were shown in Table 1 . It can be seen that these compounds showed significant variations between the plants parts tested. The content of Rutin in leaf extract was found to be higher in petroleum ether $(0.51 \%)$ than in chloroform (0.22\%) and methanol extracts (0.12\%) whereas in bark extract was resulted to be higher in petroleum ether $(0.67 \%)$ than in chloroform $(0.65 \%)$ and methanol extracts $(0.56 \%)$ (Table 1$)$. The content of Catechin in leaf extract was found to be higher in petroleum ether extract $(1.88 \%)$ than in methanol $(1.72 \%)$ and chloroform $(1.56 \%)$ whereas in bark extract was studied to be higher in petroleum ether extract $(4.29 \%)$ than in chloroform (1.73\%) and methanol extract (1.24\%) (Table 1). However, the contents of Rutin and Catechin presence found to be more in bark extracts than the leaf extracts. From the Kaempferol content studies it was in trace or absent.

Relation among DPPH scavenging activity, total Phenolic, and its flavonoid compounds

According to the results of the current study correlation between the content of either total phenolic or individual flavonoids and DPPH scavenging activity was calculated. There were a positive linear relationship between total phenolic content and DPPH scavenging activity of both leaf and bark extracts $\left(r^{2}=0.86\right.$ and $r^{2}=0.98$ respectively). A highly significant correlation was found in bark extracts between total phenolic content and DPPH scavenging activity. The correlation with catechin and rutin in leaf and bark extracts were $r^{2}=0.99$ and $r^{2}=$ $0.54 ; r^{2}=0.39$ and $r^{2}=0.98$ respectively. Thus rutin in leaf and catechin in bark extracts were found to be decreased.

\section{Anti-dermatophytic activity and MIC of extracts}

The extracts exhibited a moderate anti-dermatophytic activity against the tested fungal pathogens. As shown in Table 2, different solvent extracts from leaf (9 mg/well) showed potent inhibitory effect on the growth of $M$. canis 3270 and M. gypseum 2819 (13 $\mathrm{mm}$ in radial) by petroleum ether; $M$. canis 3270 (14 $\mathrm{mm}$ in radial) by chloroform and T. ajelloi 4878 (19 $\mathrm{mm}$ in radial) by methanol. Again, different solvent extracts from bark exhibited the efficacy on the inhibition by petroleum ether of $M$. canis 3270 (15 $\mathrm{mm}$ in radial), by chloroform of M. gypseum 2819 (14 $\mathrm{mm}$ in radial) and by methanol 
Table 2 Anti-dermatophytic activity (zone of inhibition and MIC) of Xylosma longifolium extracts compared with commercial antibiotic $16 \mu \mathrm{g} / \mathrm{ml}$ Amphotericin-B

\begin{tabular}{|c|c|c|c|c|c|c|c|c|c|}
\hline Part of plant & Extracts & Anti-dermatophytic activity & MB & MC-1 & MC-2 & MG & TA & TR-1 & TR-2 \\
\hline \multirow[t]{6}{*}{ Leaf } & PE & A & - & $10 \pm 1.3^{c}$ & $13 \pm 1.4^{c}$ & $13 \pm 1.6^{d}$ & $10 \pm 1.4^{c}$ & - & - \\
\hline & & B & $>9$ & 2.25 & 1.125 & 1.125 & 2.25 & $>9$ & $>9$ \\
\hline & $\mathrm{CH}$ & A & $10 \pm 1.6^{\mathrm{d}}$ & $10 \pm 1.3^{c}$ & $14 \pm 1.6^{d}$ & - & $11 \pm 1.2^{c}$ & - & - \\
\hline & & B & 2.25 & 2.25 & 0.562 & $>9$ & 2.25 & $>9$ & $>9$ \\
\hline & ME & A & $10 \pm 1.2^{c}$ & $13 \pm 1.3^{c}$ & $14 \pm 1.3^{c}$ & - & $19 \pm 1.5^{c}$ & - & $10 \pm 1.1^{c}$ \\
\hline & & B & 2.25 & 1.125 & 2.25 & $>9$ & 0.140625 & $>9$ & 2.25 \\
\hline \multirow[t]{6}{*}{ Bark } & PE & A & - & - & $15 \pm 1.2^{c}$ & $10 \pm 1.4^{c}$ & $12 \pm 1.2^{c}$ & $10 \pm 1.4^{c}$ & $10 \pm 1.4^{c}$ \\
\hline & & B & $>9$ & $>9$ & 0.5625 & 2.25 & 2.25 & 2.25 & 2.25 \\
\hline & $\mathrm{CH}$ & A & - & - & $10 \pm 1.3^{c}$ & $14 \pm 1.4^{c}$ & $12 \pm 1.5^{c}$ & $11 \pm 1.3^{c}$ & $12 \pm 1.4^{c}$ \\
\hline & & B & $>9$ & $>9$ & 2.25 & 0.5625 & 2.25 & 2.25 & 1.125 \\
\hline & ME & A & - & - & $13 \pm 1.2^{c}$ & $13 \pm 1.2^{c}$ & $15 \pm 1.4^{c}$ & $12 \pm 1.2^{c}$ & $14 \pm 1.3^{c}$ \\
\hline & & B & $>9$ & $>9$ & 2.25 & 2.25 & 0.28125 & 2.25 & 1.125 \\
\hline \multirow{2}{*}{\multicolumn{2}{|c|}{ Amphotericin-B }} & A & $16 \pm 0.9^{b}$ & $17 \pm 1.0^{\mathrm{b}}$ & $19 \pm 1.0^{b}$ & $19 \pm 0.8^{b}$ & $20 \pm 1.1^{c}$ & $16 \pm 0.9^{b}$ & $18 \pm 1.1^{c}$ \\
\hline & & B & 1 & 0.125 & 0.06 & 0.25 & $<0.06$ & 0.25 & 0.125 \\
\hline \multicolumn{2}{|c|}{ DMSO } & - & - & - & - & - & - & - & \\
\hline
\end{tabular}

A - The values (average of triplicate) are radial of zone of inhibition at $9 \mathrm{mg} / \mathrm{ml} ; \mathrm{B}-\mathrm{MIC}(\mathrm{mg} / \mathrm{ml}) \mathrm{mean}$ value $\mathrm{n}=3, \mathrm{P}<0.05$.

PE - Petroleum ether; $\mathrm{CH}$ - Chloroform; ME - Methanol.

Microsporum boullardii MTCC 6059 - MB; M. canis MTCC 2820 - MC-1; M. canis MTCC 3270 - MC-2; M. gypseum MTCC 2819 - MG; Trichophyton ajelloi MTCC 4878 -TA; T. rubrum MTCC 296 - TR-1; T. rubrum MTCC 3272 - TR-2; - no activity.

Means \pm SD of triplicates. For each column, values followed by one or more of the same letters were not significant different at $P<0.05$.

of T. ajelloi 4878 (15 $\mathrm{mm}$ in radial) against all the fungal pathogens tested (Table 2). Thus comparative evaluation of the extracts showed variation in the levels of activity against the tested fungal strains (Table 2). This variation of susceptibility from one species to another is evident from their zones of inhibition. In general, M. canis 3270 and T. ajelloi 4878 were found to be the most susceptible organisms to both methanol extracts of leaf and bark and requires chemical characterization for its bioactive principle. The diluted concentration of each extracts $(4.5,2.25,1.125 \mathrm{mg} / \mathrm{ml})$ did not show antidermatophytic activity.

According to the results (Table 2), the MICs of different leaf extracts on $M$. boullardii 6059, M. canis 2820, M. canis 3270, M. gypseum 2819, T. ajelloi 4878, T. rubrum 296, T. rubrum 3272 were found to be 2.25 , $2.25,0.5625,1.125,0.140625,>9,>9 \mathrm{mg} / \mathrm{ml}$, respectively. M. canis 3270 and T. ajelloi 4878 were found to be the most susceptible fungal pathogens to the chloroform and methanol leaf extracts of $X$. longifolium, respectively. Also the different dark extracts displayed potential effect of anti-dermatophytic activity as minimum inhibitory concentrations against the tested fungal pathogens, with their respective MIC values of $M$. boullardii 6059, $M$. canis 2820, M. canis 3270, M. gypseum 2819, T. ajelloi 4878, T. rubrum 296, T. rubrum 3272 were found to be $>9$, >9, 0.5625, 2.25, 0.28125, 2.25, $2.25 \mathrm{mg} / \mathrm{ml}$, respectively. As control, the DMSO did not affect the growth of the sample strains at the concentration used in this study. However, low to moderate anti-dermatophytic effect $(9-0.140625 \mathrm{mg} / \mathrm{ml})$ of bark extracts was observed against the tested fungal pathogens as a minimum inhibitory concentration. Highest sensitivity was shown by the entire test microbial towards leaf methanol extract against fungus $T$. ajelloi MTCC $4878(\mathrm{MIC}=0.140625$ $\mathrm{mg} / \mathrm{ml}$ ). The values of the plant extracts were compared with that of the reference antifungal drug AmphotericinB (Table 2).

\section{Discussions}

In this study, the extraction of both leaf and bark was performed using three solvents of increasing polarity. Different solvent systems have been used for extractions from plant material [38] because the extraction yield is dependent on the polarity and the nature of solvents [39]. Trabelsi et al. [40] showed that the methanol is the best solvent to extract total phenolics. The ANOVA for all parameters assessed a significant influence on phenolic contents, antioxidant and antimicrobial activities of plant extracts. ANOVA is just a material used to look for significant differences.

The antioxidant activity of the extracts was determined using a DPPH scavenging assay. The DPPH assay is often used to evaluate the ability of antioxidants to scavenge free radicals which are known to be a major factor in biological damages caused by oxidative stress. This assay is known to give reliable information concerning the antioxidant ability of the tested 
compounds [41]. The principle of the assay is based on the colour change of the DPPH solution from purple to yellow as the radical is quenched by the antioxidant [42].

These results were consistent with the findings of many research groups who reported such correlation between total phenolic content and $\mathrm{SCa}_{50}$ antioxidant activity [43-46]. The Folin-Ciocalteu assay used herein provides a crude estimation of the total phenolic compounds present in the extracts. Since it is not specific to polyphenols any interfering compounds may react with the reagent and thus leads to noticeable elevated phenolic concentrations [47]. In addition, phenolic compounds respond differently in this assay when the number of phenolic groups varies [27]. Several studies showed good correlation between total phenols and antioxidant activity [42,48-50].

Correlation between the content of either total phenol or individual flavonoids and antioxidant capacity data indicate that the antioxidant activity was obtained directly from phenolics, and also particularly catechin and rutin, and assures other experiments that mentioned the same vital role of catechin and rutin in lipid peroxidation inhibition $[51,52]$.

In the present study, methanol leaf and bark extracts showed high antioxidant activities as compared to the other crude extracts. This is due to bioactive compounds such as polyphenols including tannins, flavonoid existed in high polar extracts [53]. Polyphenols are one of the major plant compounds with antioxidant activity. The antioxidant activity of phenolic compounds is reported to be mainly due to their redox properties [54], which can play an important role in adsorbing and neutralizing free radicals, quenching singlet and triplet oxygen, or decomposing peroxides. Organic extracts may be more beneficial than isolated constituents, because other compounds present in the extracts can change the chemical or biological properties of bioactive individual component [55].

Phenolic was also found to be one of the most constituents in both methanol leaf and bark extracts of $X$. longifolium. These may be due to the presence of high bioactive compounds as compared to other organic extracts. The key role of phenolic compounds to scavenge free radicals has been emphasized in several reports [56-62]. The phenolic compounds may contribute directly to the antioxidant action [63]. Total phenol content in the leaf and bark are comparable but varies with the extracting solvent, methanol been the best extracting solvent, follow by chloroform and petroleum ether.

RP-HPLC analysis is the most widely used method for the identification of plant flavonoid compounds. Because of the diversity and complexity of natural flavonoid in medicinal plants, it is difficult to characterize every compound and elucidate its structure. In $X$. longifolium leaf and bark extracts of petroleum ether result the presence of high flavonoids than other extracts. Flavonoid compounds can be defined as a large series of chemical constituents possessing at least one aromatic ring, bearing hydroxyl and other sub-constituents [64]. Increasingly, flavonoids are becoming the subject of medical research. They have been reported to possess many useful properties, including anti-inflammatory activity, oestrogenic activity, enzyme inhibition, antimicrobial activity, antiallergic activity, antioxidant activity, vascular activity and cytotoxic anti-tumour activity [26,65-71]. For centuries, preparations that contain flavonoids as the principal physiologically active constituents, have been used by physicians and lay healers, in attempts to treat human diseases [65]. Owing to the widespread ability of flavonoids to inhibit spore germination of plant pathogens, they have been proposed for use against fungal pathogens in man [66].

Natural products may constitute an appropriate source of anti-infective agents. For example, flavonoids showed antimicrobial activity [69]. In fact, rutin displayed various biological activities that are beneficial to human health [72]. Studies showed that rutin give high positive correlation with DPPH in bark extracts. This is in agreement with previous study [73] which reported that the antimicrobial spectrums of the catechins. Catechin is the most represented individual flavonoid in all extracts and is best extracted by petroleum ether. The higher concentration is found in leaf.

There is a constant striving to develop safe and new natural antifungal agent to cure the fungal disorders of the increasing social and health implications, where the dermatophytes estimated lifetime risk of acquiring infection. Methods for less deleterious side effects of treatments include use of natural antifungal agents from essential oils and extracts than synthetic drugs [74].

In general, extracts derived from plants are considered as non-phytotoxic compounds and potentially effective against several microorganisms including many fungal and bacterial pathogens [75,76]. Since ancient times, interest have been given on the development of safer antifungal agents to control severe fungal diseases by the extracts and essential oils [76-78]. The results of the antifungal screening showed that the methanol leaf extract of $X$. longifolium have potential anti-dermatophytic activity against some of the skin fungal pathogens. This might be due to the presence of several bioactive compounds in extract of $X$. longifolium as evident by the finding of others [20-26,74-79]. Globally, the antidermatophytic activities of all the extracts are very low and seem not to be directly link to their total phenol and individual flavonoids contents. Besides, millions of people throughout the world are affected by superficial fungal infections, which are the most common skin 
diseases. These infections, which occur in both healthy and immune persons, are caused mainly by dermatophytes. In this study, it was observed that both leaves and barks methanol extracts of $X$. longifolium have great potential to inhibit the T. ajelloi 4878, causing superficial fungal infections of the skin known as tinea infections.

Antimicrobial activities observed in this study might be due to the presence of flavonoid compounds or various other bioactive compounds. Extracts from various medicinal plants containing phenolic and flavonoids compounds have been previously reported to possess antimicrobial activity $[80,81]$. The properties of gallic, caffeic acids, vanillic acid, rutin, and quercetin of different wine were investigated against pathogenic microorganisms [82]. The presence of these compounds might contribute to antimicrobial activity [20,22-26,77]. The flavonoid compounds have antimicrobial activity against human pathogenic microorganisms with some mechanisms of action such as inhibition of nucleic acid synthesis, cytoplasmic membrane function and energy metabolisms. The antimicrobial activity of the extracts of $X$. longifolium might be due to one of such mechanisms of action mentioned above.

The results of this study suggested that $X$. longifolium extracts can be used against many tinea infections such as Epidermophyton sp., Microsporum sp. and Trichophyton sp. where the pathogens have developed resistance against the specific fungicides $[24,26,83,84]$. The development of natural antifungal agents would also help to decrease the negative impact of synthetic agents such as residues, resistance and environmental pollution.

\section{Conclusions}

The results of our study may partially justify the folkloric uses of this plant in traditional medicine and further provide an evidence that the leaf extract of Xylosma longifolium might be indeed a potential sources of antimicrobial agents as well as natural antioxidants. Further studies are required to isolate and characterize the bioactive molecules present in organic extracts of $X$. longifolium to evaluate proper action mechanism of the observed activities.

\section{Abbreviations \\ DMSO: Dimethyl sulfoxide; DPPH: 1,1-Diphenyl-2-Picrylhydrazyl; DW: Distilled water.}

\section{Competing interests}

The author(s) declare that they have no competing interests.

\section{Authors' contributions}

RDW carried out the major portion of the work while BSS contribute in the HPLC part. BSC supervised the overall work. All authors the proofread and approved the final manuscript.

\section{Acknowledgement}

The authors are thankful to the Department of Biotechnology, Govt. of India, New Delhi for DBT-RA fellowship to W.R. Devi and also thank to Dr. Gusheinzed Waikhom, Dr. S. Sanjabihari, Mangi, Babuchandra, Bidya and

Tonsing for their valuable suggestions and Lab. supports.

Received: 17 August 2012 Accepted: 2 May 2013

Published: 2 July 2013

\section{References}

1. Ozsoy N, Can A, Yanardag R, Akev N: Antioxidant activity of Smilax excelsa leaf extracts. Food Chem 2008, 110:571-583.

2. Silva BA, Ferreres F, Malva JO, Dias ACP: Phytochemical and antioxidant characterization of Hypercium perforatum alcoholic extracts. Food Chem 2005, 90:157-167.

3. Sacchetti G, Maietti S, Muzzoli M, Scaglianti M, Manfredini S, Radice M: Comparative evaluation of 11 essential oils of different origin as functional antioxidants, antiradicals and antimicrobials in foods. Food Chem 2005, 91:621-632.

4. Mothana RAA, Lindequist U: Antimicrobial activity of some medicinal plants of the Island Sogotra. J Ethnopharmacol 2005, 96:177-181.

5. Bajpai M, Pande A, Tewari SK, Prakash D: Phenolic content and antioxidant activity of some food and medicinal plants. Int J Food SC Nut 2005, 56(4):287-291.

6. Wojdylo A, Oszmianski J, Czemerys R: Antioxidant activity and phenolic compounds in 32 selected herbs. Food Chem 2007, 105:940-949.

7. Rios JL, Recio MC: Medicinal plants and antimicrobial activity. J Ethnopharmacol 2005, 100:80-84.

8. Kuete V, Wansi JD, Mbaveng AT, Kana SMM, Tadjon AT, Beng VP, Etoa FX, Wandji J, Meyer JJM, Lall N: Antimicrobial activity of the methanolic extract and compounds from Teclea afzelii (Rutaceae). South Afric J Bot 2008, 74:572-576.

9. Sonibare MA, Soladoye MO, Esan OO, Sonibare OO: Phytochemical and antimicrobial studies of four species of Cola Schott \& Endl. (Sterculiaceae). Afri J Trad Complem Alter Med 2009, 6(4):518-52.

10. Kuete $\mathrm{V}$ : Potential of Cameroonian plants and derived-products against microbial infections: A review. Planta Med 2010, 76:1-13.

11. Jessup CJ, Warner J, Isham N, Hasan I, Ghannoum MA: Antifungal susceptibility testing of dermatophytes: establishing a medium for inducing conidial growth and evaluation of susceptibility of clinical isolates. J Clin Microbiol 2000, 38(1):341-344.

12. Curtis C: Use and abuse of topical dermatological therapy in dogs and cats. Part 1. Shampoo. Ther Pract 1998, 20:244-251.

13. Baker JH, Goodpasture HC, Kuhns HR, Rinaldi MC: Fungemia caused by an Amphotericin B-resistant isolate of Sporothrix schenckii. Arch Pathol Lab Med 1989, 113:1279-1281.

14. Willocks L, Leen CLS, Brettle RP, Urquart D, Russel TB, Milne JR: Fluconazole resistance in AIDS patients. J Antimicrob Chemother 1991, 28:937-939.

15. Khare CP: Indian medicinal plants: an illustrated dictionary. Springer-Verlag 2007, Berlin Heidelberg, New York:725.

16. Chadha HR: The wealth of India raw materials, Publication and Information Directorate New Delhi: CSIR; 2003. XI:11.

17. Sinha SC: Medicinal plants of Manipur, (Manipur Association for Science \& Society (MASS), Manipur Cultural Integration Conference (MCIC) Publishers, Palace Compound, Imphal). Calcutta: Manasi Printers; 1996.

18. Peter $\mathrm{H}$ : Institute of genetics and crop plant research. In Mansfeld's Encyclopedia of Agricultural and Horticultural Crops (Except Ornamentals. Berlin Heidelberg, New York: Springer-Verlin; 2001:1374.

19. Catherina CG, Mahabir PG: A quarter century of pharmacognostic research on panamanian flora: a review. Planta Med 2011, 77:1189-1202.

20. Mosaddik MA, Banbury L, Forster P, Booth R, Markham J, Leach D, Waterman PG: Screening of some Australian flacourtiaceae species for in vitro antioxidant, cytotoxic and antimicrobial activity. Phytomedicine 2004, 11(5):461-466.

21. Andressa FP: Caracterização fitoquímica e atividades biológicas De Xylosma ciliatifolium (Clos) eichler, flacourtiaceae (salicaceae Sensu Lato). Dissertation: Universidade Federal Do Paraná Curitiba; 2010.

22. Castro SBR, Leal CAG, Freire FR, Carvalho DA, Oliveira DF, Figueiredo HCP. Antibacterial activity of plant extracts from brazil against fish pathogenic bacteria. Braz J Microbiol 2008, 39:756-760. 
23. Hyun-Kyung L, Haeng-Byoung L, Cheol-Soo K, Young-Joon A: AntiHelicobacter pylori activity of methanol extracts from Korean native plant species in Jeju Island. Agric Chem Biotechnol 2004, 47(2):91-96.

24. Bich NT, Van CP, Huong DTM, Van HN, Manh CN, Tien HN, Hong-jie Z, Harry HSF, Scott GF, Djaja DS, Van MC: Chemical constituents from Xylosma longifolia and their anti-tubercular activity. Phytochem Lett 2011, 4(3):250-253.

25. Parveen M, Ghalib RM, Rehman R, Ali M: ChemicalConstituents from the leaves of Xylosma longifolium. Hamdard Medicus 2009, 3:47.

26. Parveen M, Ghalib RM: Flavonoids and antimicrobial activity of leaves of Xylosma longifolium. J Chil Chem Soc 2012, 57(N:1):989-991.

27. Singleton $V L$, Rossi JA: Colorimetry of total phenolics with phosphomolybdic-phosptungslic acid reagents. Am J Enol Viticult 1965, 16:144-158.

28. Okada Y, Okada M: Scavenging effect of soluble proteins in broad beans on free radicals and active oxygen species. J Agric Food Chem 1998, 46:401-406.

29. Chapuis-Lardy L, Contour-Ansel D, Bernhard-Reversat F: High-performance liquid chromatography of water-soluble phenolics in leaf litter of three Eucalyptus hybrids (Congo). Plant Sci 2002, 163:217-222.

30. Yuangang Z, Chunying L, Yujie F, Chunjian Z: Simultaneous determination of catechin, rutin, quercetin, kaempferol and isorhamnetin in the extract of sea buckthorn (Hippophae rhamnoides L.) leaves by RP-HPLC with DAD. J Pharm Biomed Anal 2006, 41:714-719.

31. Kumar BSA, Lakshman K, Jayaveera KN, Krishna NV, Manjunat M, Suresh MV: Estimation of rutin and quercetin in Amaranthus viridis Linn. by HPLC. Asian J Exp Sci 2009, 23(1):51-54.

32. Huafu W, Gordon JP, Keith H: HPLC determination of catechins in tea leaves and tea extracts using relative response factors. Food Chem 2003, 81(2):307-312.

33. Yi W, Jiang C, Jiang-Hua W, Su Z: Simultaneous determination of quercetin, kaempferol and iso-rhamnetin accumulated human breast cancer cells, by high performance liquid chromatography. J Pharm Biomed Anal 2005, 39:328-333.

34. NCCLS (National Committee for Clinical Laboratory Standards): Specialty Collection: Susceptibility Testing. SC21-L. M7-A4. Wayne, PA: NCCLS; 1997.

35. Jennifer MA: Determination of MICs. J Antimicrobial Chemotherapy 2001 48(S1):5-16.

36. Reeves DS, Phillips I, Williams JD: Laboratory methods in antimicrobial Chemotherapy. Edinburgh: Longman Group Ltd; 1979:20.

37. Murray PR, Baron EJ, Pfaller MA, Tenover FC, Yolke RH: Manual of clinical microbiology. Sixth ed. ASM Washington 1995, 9(S1):S42-S46.

38. Karmanoli K: Secondary metabolites as allelochemicals in plant defence against microorganisms of the phyllosphere. In Allelopathy from molecules to ecosystem. Edited by Reigosa M, Pedrol N. NH, USA: Science publishers Inc.; 2002:277-288

39. Pinelo M, Rubilar M, Sineiro J, Nunez MJ: Extraction of antioxidant phenolics from almond hulls (Prunus amygdalus) and pine sawdust (Pinus pinaster). Food Chem 2004, 85:267-273.

40. Goli A, Barzegar M, Sahari MA: Antioxidant activity and total phenolic compounds of pistachio (Pistachia vera) hull extracts. Food Chem 2004, 92:521-525.

41. Trabelsi N, Megdiche W, Ksouri R, Falleh H, Oueslati S, Soumaya B, Hajilaoui $H$, Abdelly C: Solvent effects on phenolic contents and biological activities of the halophytes Limoniastrum monopetalum leaves. LWT - Food Sci Tech 2010, 43:632-639.

42. Huang D, Ou B, Prior RL: The chemistry behind antioxidant capacity assays. J Agric Food Chem 2005, 53:1841-856.

43. Karagozler AA, Erdag B, Emek YC, Uygun DA: Antioxidant activity and proline content of leaf extracts from Dorystoechas hastate. Food Chem 2008, 111:400-407.

44. González EM, de Ancos B, Cano MP: Relation between bioactive compounds and free radical-scavenging capacity in berry fruits during frozen storage. J Sci Food Agric 2003, 83:722-726.

45. Llobera A, Cañellas J: Dietary fibre content and antioxidant activity of Manto Negro red grape (Vitis vinifera): Pomace and stem. Food Chem 2007, 101:659-666.

46. Makris DP, Boskou G, Andrikopoulos NK: Polyphenolic content and in vitro antioxidant characteristics of wine industry and other agri-food solid waste extracts. J Food Comp Anal 2007, 20:125-132.

47. Lecumberri E, Mateos R, Izquierdo-Pulido M, Rupérez P, Goya L, Bravo L: Dietary fibre composition, antioxidant capacity and physico-chemical properties of a fibrerich product from cocoa (Theobroma cacao L.). Food Chem 2007, 104:948-954.
48. Prior RL, Wu X, Schaich K: Standardized methods for the determination of antioxidant capacity and phenolics in foods and dietary supplements. J Agric Food Chem 2005, 53:4290-4302.

49. Bourgou S, Ksouri R, Bellila A, Skandrani I, Falleh H, Marzouk B: Phenolic composition and biological properties and potential apllications in food-a review. Int J Food Microbiol 2008, 94:223-253.

50. Falleh H, Ksouri R, Chaieb K, Karray-Bouraoui N, Trabelsi N, Boulaaba M, Abdelly C: Phenolic composition of Cynara cardunculus L. organs, and their biological activities. C R Biol 2008, 331:372-379.

51. Verstraeten SV, Keen CL, Schmitz HH, Fraga CEG, Oteiza PI: Flavan-3-Ols and procyanidins protect liposomes against lipid oxidation and disruption of the bilayer structure. Free Radic Biol Med 2003, 34(1):84-92.

52. Lotito SB, Fre B: Relevance of apple polyphenols as antioxidants in human plasma: contrasting in vitro and in vivo effects. Free Radic Biol Med 2004, 36(2):201-211.

53. Al-Obid MR: Date skin as a source of antioxidant activity and free radical scavenging. First International Meeting of Date Palm Phoenix dactylifera L Qas- sim 2003:643-658

54. Galato D, Ckless K, Susin MF, Giacomelli C, Riberio Do Valle RM, Spineeli A: Antioxidant capacity of phenolic and related compounds: correlation among electrochemical, visible spectroscopy methods and structure antioxidant activity. Redox Rep 2001, 6:250.

55. Borchers AT, Keen $\mathrm{Cl}$, Gerstiwin ME: Mushrooms, tumors and immunity: an update. Exp Biol Med 2004, 229:393-406.

56. Rauha JP, Remes S, Heinonen M, Hopia A, Kahkonen M, Kujala T, Pihlaja K, Vuorela H, Vuorela P: Antimicrobial effects of Finnish plant extracts containing flavonoids and other phenolic compounds. In J Food Microbiol 2000, 56:3-12

57. Archana B, Dasgupta N, De B: In vitro study of antioxidant activity of Syzgium cumini fruit. Food Chem 2005, 90:727-733.

58. Hatano T, Edamatsu R, Mori A, Fujita Y, Yasuhara E: Effect of interaction of tannins with co-existing substances. VI. Effects of tannins and related polyphenols on superoxide anion radical and on DPPH radical. Chem Pharm Bul 1989, 37:2016-2021.

59. Velioglu YS, Mazza G, Gao L, Oomah BD: Antioxidant activity and total phenolics in selected fruits, vegetables and grain products. J Agric Food Chem 1998, 46:4113-4117.

60. Vinson JA, Young $H$, Xuchui S, Zubik L: Phenol antioxidant quantity and quality in foods: vegetables. J Agric Food Chem 1998, 46:3630-3634.

61. Gülçin I, Oktay M, Küfrevioğlu Öl, Aslan A: Determination of antioxidant activity of lichen Cetraria islandica (L.) Ach. J Ethnopharmacol 2002, 79:325-329.

62. Oktay M, Gülçin I, Küfrevioğlu Öl: Determination of in vitro antioxidant activity of fennel (Foeniculum vulgare) seed extracts. LebensmittelWissenchaft und Technologie 2003, 36:263-271.

63. Duh PD, Tu YY, Yen GC: Antioxidant activity of water extract of Harug Jyur (Chrysanthemum morifolium Ramat). Lebensmittel-Wissenchaft und Technologie 1999, 32:269-277.

64. Ribereau-Gayon P: Notions generales sur les composes phenoliques, methodes generales d'etudes des composes phenoliques. In Les Composés Phenoliques des Vegetaux. Edited by Dunod. Paris; 1968.

65. Havsteen B: Flavonoids, a class of natural products of high pharmacological potency. Biochem Pharmacol 1983, 32:1141-8.

66. Harborne JB, Williams CA: Advances in flavonoid research since 1992. Phytochem 2000, 55:481-504

67. Harborne JB, Baxter H: The handbook of natural flavonoids. Vols 1 and 2. Chichester, UK: John Wiley and Sons; 1999

68. JrE M, Chithan K: The impact of plant flavonoids on mammalian biology: implications for immunity, inflammation and cancer. In The flavonoids: advances in research since 1986. Edited by Harborne JB. London, UK: Chapman and Hall; 1993.

69. Baise HP, Walker TS, Stermitz FR, Hufbauer RS, Vivanco JM: Enantiometric dependent phytotoxic and antimicrobial activity of ( \pm )-catechin; a rhizosecreted racemic mixture from Centaurea maculosa (spotted knapweed). Plant Physiol 2002, 128:1173-1177.

70. Cushnie T, Lamb A: Antimicrobial activity of flavonoids. Int J Antimicrob Agents 2005, 26(5):343-356.

71. Shimamura T, Zhao WH, Hu ZQ: Mechanism of action and potential for use of tea catechin in an anti-infective agent. Anti-infective Agents in Medic Chem 2007, 6:57-62.

72. Tavares AC, Goncalves MJ, Cavaleira C, Cruz MT, Lopes MC, Canhoto J, Salgueiro LR: Essential oil of Daucus carota subsp. halophilus: 
composition, antifungal activity and cytotoxicity. J Ethnopharmacol 2008, 119:129-134.

73. Koda T, Kuroda Y, Imai H: Protective effect of rutin against spatial memory impairment induced by trimethyltin in rats. Nutr Res 2008, 28:629-634.

74. Kabuki T, Nakajima H, Arai M, Ueda S, Kuwabara Y, Dosaka S: Characterization of novel antimicrobial compounds from mango (Mangifera indica L.) kernel seeds. Food Chem 2000, 50:565-570.

75. Perry NB, Foster $L M$ : Antiviral and antifungal flavonoids, plus triterpene from Hebe cuppressoides. Plants Med 1994, 60:491-492.

76. Pandey DK, Tripathi NN, Tripathi RD, Dixit SN: Fungitoxic and phytotoxic properties of the essential oil Caesulia axillaris Roxb. Angewa Bot 1982, 56:259-267.

77. Chung PH, Lee CW, Chou JY, Murugan M, Shieh BJ, Chen HM: Antifungal activity of crude extracts and essential oil of Moringa olifera Lam. Bioresour Technol 2007, 98:232-236.

78. Prasad NR, Anandi C, Balasubramania S, Pugalendi KV: Antidermatophytic activity of extracts from Psoralea corylifolia (Fabaceae) correlate with the presence of a flavonoid compound. J Ethnopharmacol 2004, 91:21-34.

79. Vivek KB, Jung IY, Sun CK: Antioxidant and antidermatophytic activities of essential oil and extracts of Magnolia liliflora Desr. Food Chem Toxicol 2009, 47:260-2612

80. Urzua A, Torre R, Bueno C, Mendoza L: Flavonoids and diterpenoids in the trichome resinous exudate from Psudeognaphalium cheivanthifolium. P. heterotrichium and P. vira vira. Biochem Syst Ecol 1995, 23:459.

81. Ayaz F, Haylrlloglu-Ayaz S, Alpay-Karaoglu S, Gruz J, Valentová K, Ulrichová J, Starnad M: Phenolic acid contents of kale (Brassica oleraceae L. var. acephala DC.) extracts and their antioxidant and antibacterial activities. Food Chem 2008, 107:19-25.

82. Rahman M, Moon S: Antimicrobial phenolic derivatives from Dendranthema zawadskii var. latilobum kitamura (Asteraceae). Arch Pharm Res 2007, 30:1374-1379.

83. Vaquero MJR, Alberto MR, de Nadra MCM: Antibacterial effect of phenolic compounds from different wines. Food Control 2007, 18:93-101.

84. Ghannoum MA, Rice LB: Antifungal agents: mode of action, mechanisms of resistance, and correlation of these mechanisms with bacterial resistance. Clin Microbial Rev 1999, 12(4):501-517.

doi:10.1186/1472-6882-13-155

Cite this article as: Devi et al:: Antioxidant and anti-dermatophytic properties leaf and stem bark of Xylosma longifolium clos. BMC

\section{Submit your next manuscript to BioMed Central and take full advantage of:}

- Convenient online submission

- Thorough peer review

- No space constraints or color figure charges

- Immediate publication on acceptance

- Inclusion in PubMed, CAS, Scopus and Google Scholar

- Research which is freely available for redistribution

Submit your manuscript at www.biomedcentral.com/submit
(O) Biomed Central 